\title{
Hubungan antara Perfeksionisme dengan Kecenderungan Kecemasan Sosial pada Remaja Akhir Pengguna Instagram
}

\author{
BELINDA FIDI MADANI \& TRI KURNIATI AMBARINI* \\ Departemen Psikologi Klinis dan Kesehatan Mental, Fakultas Psikologi Universitas Airlangga
}

\begin{abstract}
ABSTRAK
Instagram telah memberikan fasilitas bagi remaja akhir dalam pemenuhan perkembangan sosialnya. Namun, penggunaan Instagram dapat memberikan beberapa dampak kerugian psikologis, salah satunya adalah kecemasan sosial. Instagram sebagai media sosial berbasis visual telah mendorong penggunanya untuk mencapai kesempurnaan dan sifat kepribadian perfeksionisme dapat meningkatkan kecenderungan kecemasan sosial. Penelitian ini dilakukan untuk mengetahui apakah terdapat hubungan antara perfeksionisme dengan kecenderungan kecemasan sosial, dengan partisipan yaitu remaja akhir pengguna Instagram di Indonesia $(N=333)$. Data diperoleh melalui survei secara daring menggunakan skala Perfectionistic Self-Presentation Scale (PSPS) dan Social Anxiety Scale for Adolescents (SAS-A). Analisis data dilakukan dengan uji korelasi Pearson Product-Moment dan mendapatkan hasil bahwa terdapat hubungan signifikan antara perfeksionisme dan kecenderungan kecemasan sosial pada remaja akhir pengguna Instagram $(r=0,408 ; p=0,000)$. Dapat diartikan bahwa, apabila remaja akhir pengguna Instagram memiliki perfeksionisme yang tinggi, maka akan tinggi pula kecenderungan mereka mengalami kecemasan sosial.
\end{abstract}

\section{Kata kunci: Instagram, kecemasan sosial, perfeksionisme, remaja akhir}

\begin{abstract}
Instagram has facilitated late adolescents to fulfill their social development. However, Instagram use can lead to several psychological distress, such as social anxiety. Instagram, a visual-based social media, has encouraged its users to achieve perfection, and perfectionism personality traits can increase the tendency of social anxiety. This study was conducted to determine whether there is a relationship between perfectionism and a tendency to social anxiety in late adolescents using Instagram in Indonesia $(N=333)$. Data were collected through online surveys using the Perfectionistic Self-Presentation Scale (PSPS) and the Social Anxiety Scale for Adolescents (SAS-A). Data were analyzed using Pearson ProductMoment correlation test and it is found that there was a significant relationship between perfectionism and social anxiety tendencies in late adolescents using Instagram $(r=0.408 ; p=0.000)$. This result indicated that the higher perfectionism in late adolescents using Instagram, the higher their tendency to experience social anxiety.
\end{abstract}

Keywords: Instagram, late adolescent, perfectionism, social anxiety 
Naskah ini merupakan naskah dengan akses terbuka dibawah ketentuan the Creative Common Attribution License (CC-BY-4.0) (http://creativecommons.org/licenses/by/4.0), sehingga penggunaan, distribusi, reproduksi dalam media apapun atas artikel ini tidak dibatasi, selama sumber aslinya disitir dengan baik.

\section{PEN D A H U L U A N}

Pada jaman di saat teknologi sangat berkembang pesat ini, hampir seluruh individu memiliki dan menggunakan media sosial. Terdapat 3,8 miliar pengguna aktif media sosial di dunia dengan pertumbuhan penggunanya pada tahun 2020 bertambah 9,2\%. Di Indonesia sendiri, 59\% dari populasinya merupakan pengguna aktif media sosial (Kemp, 2020). Media sosial telah mengubah cara berinteraksi manusia menjadi lebih mudah dengan tidak membatasi antara jarak dan waktu. Penggunaan media sosial juga memiliki manfaat secara psikologis, seperti meningkatkan selfaffirmation atau penegasan diri dan keterhubungan sosial (Couture Bue, 2020). Selain itu, penggunaan media sosial juga telah dibuktikan oleh banyak penelitian bahwa dapat mengarahkan pada beberapa kerugian psikologis, seperti adiksi (Müller dkk., 2016), gangguan pada perilaku makan (Mabe dkk., 2014), serta risiko mengalami depresi dan kecemasan sosial (Dhir dkk., 2018; Vannucci dkk., 2017).

Menurut survei dari Royal Society for Public Health (2017), Instagram merupakan media sosial yang memiliki dampak paling buruk terhadap kesehatan mental remaja, terutama dalam meningkatkan depresi dan kecemasan dibandingkan dengan media sosial lain seperti Twitter, YouTube, Snapchat, dan Facebook. Instagram merupakan platform berbasis foto yang memberikan layanan kepada penggunanya untuk mengunggah gambar diri mereka sendiri dan pengguna lain akan memberikan umpan balik dalam bentuk like (suka) dan komentar (Anixiadis dkk., 2019). Di Indonesia sendiri, Instagram merupakan media sosial berbasis foto yang paling banyak digunakan (Kemp, 2020) dan penggunanya merupakan terbesar keempat di dunia per-November 2019, yaitu sebesar 61.610.000 juta (Hamdan, 2019).

Jumlah pengguna Instagram terbesar di Indonesia berasal dari kelompok remaja akhir berumur 18-24 tahun (Hamdan, 2019). Bagi remaja akhir, aspek penting untuk kesejahteraan psikologis dan fungsi sosial mereka adalah kebutuhan untuk menjadi bagian dari sebuah kelompok serta harga diri mereka secara sosial, maka dari itu penggunaan media sosial dianggap dapat memenuhi kebutuhan tersebut (Sheldon \& Bryant, 2016 dalam Longobardi dkk., 2020). Motivasi remaja akhir menggunakan media sosial adalah untuk berkoneksi dengan orang lain, mencari informasi, dan mengurangi kebosanan. Dibandingkan dengan media sosial lain, Instagram lebih banyak digunakan oleh remaja akhir untuk alasan berkoneksi dengan orang lain (Stockdale \& Coyne, 2020).

Beberapa studi telah mengatakan bahwa terdapat hubungan antara penggunaan Instagram dengan kecemasan sosial, namun mereka memiliki hasil yang berbeda mengenai faktor apa yang mendukung hal tersebut. Studi milik Jiang dan Ngien (2020) menghasilkan bahwa penggunaan Instagram dapat meningkatkan kecemasan sosial, dimediasi oleh perilaku pengguna yang cenderung melakukan perbandingan sosial secara negatif dan kepercayaan diri yang rendah. Kemudian, studi milik Erliksson dan kawan-kawan (2020) menghasilkan bahwa penggunaan Instagram dengan durasi yang lama, penggunaan secara aktif, dan penggunaan secara pasif berhubungan dengan kecemasan sosial. Hasil studi ini berbeda dengan studi sebelumnya yang dilakukan oleh Shaw dan kawan-kawan (2015), mereka mengatakan bahwa hanya penggunaan secara pasif saja yang berhubungan dengan kecemasan sosial pada pengguna media sosial. 
Kecemasan sosial merupakan perasaan takut ketika berada di situasi sosial dan ketika berada dengan orang yang tidak dikenal, individu juga khawatir akan konteks evaluasi (American Psychiatric Association, 2013). Di Indonesia sendiri, angka kecemasan sosial pada populasi mahasiswa di salah satu Universitas di Yogyakarta memiliki prevalensi sebesar 15,8\% dan lebih tinggi dibandingkan mahasiswa di Swiss (Vriends dkk, 2013). Kemudian, 52,2\% dari 364 mahasiswa pada tiga Universitas di Malang memiliki kecemasan sosial rendah hingga sedang dan 24,7\% memiliki kecemasan sosial yang tinggi (Suryaningrum dkk., 2019). Maka, dapat dikatakan bahwa banyak dari remaja berusia 18 - 21 tahun atau mahasiswa di Indonesia memiliki kecemasan sosial.

Kecemasan sosial secara garis besar dapat merugikan seluruh aspek dalam kehidupan individu, seperti kesulitan dalam pekerjaan, gangguan pada sekolah, hubungan dengan orang lain, serta kegiatan lainnya (Antony \& Swinson, 2008; Butler, 1999 dalam Suryaningrum, 2016). Perasaan tidak nyaman berada di situasi sosial dan berinteraksi dengan orang lain adalah hal yang sulit, karena hal tersebut tidak dapat dihindari secara terus menerus oleh individu.

Individu dengan kecemasan sosial cenderung akan berpikir dan berperilaku serupa baik dalam interaksi secara tatap muka maupun secara daring. Mereka akan merasakan tingkat kecemasan yang tinggi, melakukan safety behaviors, memiliki banyak pemikiran negatif, dan cenderung menafsirkan keadaan secara negatif ketika berinteraksi baik secara daring maupun luring (Carruthers dkk., 2019).

Instagram sebagai platform yang menekankan pada hal visual (foto dan video), dengan banyaknya filter foto serta kemampuan retouching yang membuat setiap foto terlihat sempurna, dapat mengarahkan kepada kecemasan (Vannucci dkk., 2019). Adanya fitur filter foto yang memungkinkan pengguna untuk memperindah foto mereka telah mengubah cara individu menampilkan diri mereka secara daring, penggambaran tentang diri yang ideal dapat memengaruhi respons emosional dan psikologis pengguna lain yang melihatnya (Chua \& Chang, 2016 dalam Jiang \& Ngien, 2020). Hal tersebut membuat para penggunanya terdorong untuk mempresentasikan hal yang paling positif dan terpoles mengenai dirinya (Winter, 2013 dalam Lup dkk., 2015). Konten-konten pada media sosial Instagram memberikan harapan yang tidak realistis dan mengakibatkan anak-anak muda berusaha untuk mengejar kesempurnaan, kemudian dapat bermanifestasi sebagai kecemasan sosial (Roccaforte \& Cohen, 2017).

Menurut model self-presentation dari kecemasan sosial milik Schlenker dan Leary (1982), kecemasan sosial dapat muncul ketika seseorang termotivasi untuk membuat kesan dan menampilkan kesempurnaan kepada orang lain, meragukan kemampuan mereka untuk membuat kesan yang sempurna, serta membayangkan evaluasi tidak menyenangkan dari orang lain dalam menanggapi kegagalan tersebut. Maka dari itu, dapat dikatakan bahwa sifat kepribadian perfeksionisme merupakan salah satu faktor yang berhubungan dengan kecemasan sosial.

Perfeksionisme merupakan sebuah konstruksi yang luas. Hewitt dan kawan-kawan (2003) telah membangun salah satu konstruksi perfeksionisme yaitu perfectionistic self-presentation. Perfectionistic self-presentation merupakan sifat kepribadian yang berkomitmen untuk menampilkan dirinya secara ideal di publik tanpa adanya kecacatan (Hewitt dkk., 2003). Menurut Flett \& Hewitt (2014), peneliti yang telah mengembangkan konsep perfeksionisme multidimensional sebelumnya, mengatakan bahwa perfectionistic self-presentation merupakan konsep yang berhubungan secara kuat dan unik dengan kecemasan sosial, serta tidak dapat dijelaskan oleh dimensi perfeksionisme lainnya.

Berdasarkan penjelasan di atas, maka penelitian ini ingin mengetahui apakah terdapat hubungan antara perfeksionisme dengan kecenderungan kecemasan sosial pada remaja akhir pengguna Instagram. 
Penelitian ini memiliki hipotesis $\left(\mathrm{H}_{\mathrm{a}}\right)$ bahwa sifat kepribadian perfeksionisme pada remaja akhir pengguna Instagram berhubungan dengan kecenderungan mereka mengalami kecemasan sosial.

\section{Desain Penelitian}

\section{E T ODE}

Penelitian ini merupakan penelitian dengan pendekatan kuantitatif dan pengambilan data dilakukan melalui survei. Metode ini digunakan untuk melihat karakteristik subjek dalam jumlah yang besar (Mertens, 2010) dan objektivitas data diungkapkan melalui angka-angka serta pengolahan statistik (Hamdi \& Bahruddin, 2014). Pengambilan data dilakukan secara daring agar mudah di jangkau oleh berbagi partisipan sehingga tidak terbatas oleh jarak dan waktu. Penelitian ini juga bersifat korelasional karena akan melihat hubungan di antara perfeksionisme dengan kecemasan sosial pada remaja akhir pengguna Instagram.

\section{Partisipan}

Partisipan pada penelitian adalah 333 remaja akhir berusia 18 - 21 tahun yang memiliki akun media sosial Instagram dan bertempat tinggal di Indonesia $\left(M_{\text {usia }}=19,79 ; S D_{\text {usia }}=1,17 ; 86,2 \%\right.$ perempuan). Persebaran asal provinsi partisipan adalah sebagai berikut: 39\% asal Jawa Timur, 18,9\% asal DKI Jakarta, 13,2\% asal Jawa Barat, dan 28,9\% lainnya. Rata-rata partisipan merupakan lulusan SMA dan rata-rata memiliki 2 akun Instagram.

Metode sampling yang digunakan adalah nonprobability sampling dengan teknik purposive sampling. Ukuran partisipan ditentukan melalui penghitungan pada aplikasi $G^{*}$ Power, dengan nilai statistical power sebesar 0,95 dan least detectable effect size sebesar 0,2, didapatkan jumlah partisipan yang perlu didapatkan adalah sebesar 319 partisipan. Informasi mengenai penelitian dan informed consent telah diberikan pada kuesioner sebelum partisipan memulai pengisian skala penelitian.

\section{Pengukuran}

Perfeksionisme. Pengukuran perfeksionisme menggunakan Perfectionistic Self-Presentation Scale (PSPS; Hewitt dkk., 2003) yang telah diadaptasi ke dalam Bahasa Indonesia. Alat ukur ini memiliki 27 aitem yang terdiri dari 5 aitem unfavorable dan 22 aitem favorable. Partisipan diminta untuk merespons seberapa setuju mereka dengan setiap aitem pada rentang angka $1-7$ (1 = "sangat tidak setuju", $4=$ "netral", dan 7 = "sangat setuju") mengenai kondisi apa yang dianggap paling menggambarkan dirinya ketika melihat konten di Instagram (contoh, "Jika saya terlihat sempurna, maka orang lain akan melihat saya secara lebih positif"). Pengukuran dilakukan dengan menjumlahkan seluruh skor aitem untuk mendapatkan total skor. Alat ukur ini memiliki koefisien reliabilitas yang tinggi $(\alpha=.861)$.

Kecemasan sosial. Pengukuran kecemasan sosial menggunakan 18 aitem dari skala Social Anxiety Scale for Adolescents (SAS-A; La Greca \& Lopez, 1998) yang telah diadaptasi ke dalam Bahasa Indonesia. Partisipan diminta untuk merespons pada skala likert dengan rentang angka 1 - 5 (1 = "tidak pernah sama sekali" dan 5 = "selalu") mengenai seberapa sering mereka merasakan pernyataan tersebut pada masing-masing aitem (contoh, "Saya merasa gugup ketika saya bertemu dengan orang baru"). Total skor didapatkan dengan menjumlahkan skor pada seluruh aitem. Alat ukur ini memiliki koefisien reliabilitas yang sangat baik $(\alpha=.910)$.

Uji Asumsi. Sebelum melakukan uji korelasi, peneliti memastikan bahwa data yang digunakan untuk analisis telah memenuhi asumsi dalam melakukan uji tersebut. Hasil dari uji normalitas Kolmogorov- 
Smirnov didapatkan bahwa kedua variabel berdistribusi secara normal, masing-masing variabel memiliki nilai $p>0,05$. Kemudian, hasil uji linearitas mendapatkan bahwa terdapat hubungan linear di antara kedua variabel $(p<0,05)$. Berdasarkan kedua hasil tersebut, maka dapat dikatakan bahwa data penelitian telah memenuhi asumsi untuk dilakukan uji korelasi.

\section{Analisis Data}

Analisis data pada penelitian ini menggunakan analisis korelasi karena penelitian ini ingin melihat hubungan antara kedua variabel yaitu perfeksionisme dan kecemasan sosial pada remaja akhir pengguna Instagram. Analisis korelasi digunakan untuk menggambarkan kekuatan dan arah hubungan linear antara kedua variabel. Pengujian analisis data menggunakan uji korelasi Pearson Product-Moment karena data yang digunakan adalah data interval. Sebelum dilakukan uji korelasi, perlu dilakukan uji asumsi yaitu uji normalitas dan uji linearitas. Data yang bersifat normal dan terdapat hubungan linear di antara kedua variabelnya dapat dilakukan uji korelasi Pearson Product-Moment. Uji analisis data dilakukan dengan menggunakan program aplikasi IBM SPSS Statistic 24.0 for Windows.

\section{HAS I L P E N EL I T I A N}

Berdasarkan Tabel 1, dengan jumlah data yang diolah sebanyak 333 partisipan, variabel perfeksionisme memiliki nilai terkecil atau minimal sebesar 62 dan nilai terbesar atau maksimal sebesar 167 . Rata-rata nilai pada variabel perfeksionisme adalah 118,86 dan standar deviasi sebesar 17,473. Sedangkan, variabel kecemasan sosial memiliki nilai terkecil atau minimal sebesar 23 dan nilai terbesar atau maksimal sebesar 86. Rata-rata nilai pada variabel kecemasan sosial adalah 55,69 dan standar deviasi sebesar 11,767 .

Tabel 1. Statistik Deskriptif dan Korelasi pada Variabel Penelitian

\begin{tabular}{llllllll}
\hline Variabel & N & Min. & Max. & M & SD & $\mathbf{1}$ & $\mathbf{2}$ \\
\hline 1. Perfeksionisme & 333 & 62 & 167 & 118,86 & 17,473 & - & \\
2. Kecemasan Sosial & 333 & 23 & 86 & 55,69 & 11,767 & $0,408^{* *}$ & - \\
\hline
\end{tabular}

** $p<0,05$

$H_{\text {a }}$ pada penelitian ini adalah terdapat hubungan antara perfeksionisme dengan kecenderungan kecemasan sosial pada remaja akhir yang menggunakan Instagram. Berdasarkan hasil uji korelasi, didapatkan bahwa perfeksionisme memiliki korelasi yang positif dengan kecemasan sosial dan hubungan tersebut cenderung sedang $(r(333)=0,408 ; p<0,05)$.

\section{I S K U S I}

Penelitian ini bertujuan untuk mengetahui apakah terdapat hubungan antara perfeksionisme dengan kecenderungan remaja akhir pengguna Instagram mengalami kecemasan sosial. Hasil penelitian ini menunjukkan bahwa hipotesis penelitian ( $\mathrm{Ha}$ ) diterima, yaitu perfeksionisme memiliki hubungan yang signifikan terhadap kecenderungan kecemasan sosial pada remaja akhir pengguna Instagram. Arah

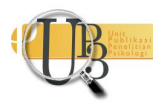


hubungan antara kedua variabel adalah bersifat positif, yaitu apabila perfeksionisme meningkat, maka kecemasan sosial juga akan meningkat.

Hasil penelitian ini sejalan dengan penelitian Hesler (2015) dan Mackinnon dan kawan-kawan (2014) yang menemukan adanya hubungan signifikan antara perfectionistic self-presentation dengan kecemasan sosial pada sampel remaja akhir. Menurut Flett dan Hewitt (2014), salah satu faktor kepribadian yang dapat meningkatkan kecemasan sosial adalah perfeksionisme. Konsep perfeksionisme yang digunakan dalam penelitian ini adalah Perfectionistic Self-Presentation, yaitu bentuk maladaptif dimana individu berusaha untuk menampilkan kesempurnaan dan menghindari menunjukkan kekurangannya secara konsisten. Individu dengan perfeksionisme memiliki tekanan dalam memenuhi standar dan ekspektasi yang sangat tinggi, tetapi mereka juga memiliki pengaturan diri yang maladaptif untuk menghindari kegagalan.

Menurut model self-presentation dari kecemasan sosial milik Schlenker dan Leary (1982), kecemasan sosial dapat terjadi ketika individu tidak mampu memenuhi standar presentasi diri mereka yang terlalu positif dan tidak realistis. Dengan menggunakan Instagram, para remaja akhir membentuk standar yang tinggi karena sifat dari media sosial tersebut hanya menampilkan hal visual, sehingga membuat para penggunanya terdorong untuk mempresentasikan hal yang paling positif dan terpoles mengenai dirinya. Konten dalam media sosial tersebut memberikan harapan tidak realistis sehingga mengakibatkan remaja akhir berusaha mengejar kesempurnaan, yang kemudian dapat bermanifestasi sebagai kecemasan sosial jika mereka tidak mampu memenuhi standar tersebut (Roccaforte \& Cohen, 2017; Winter, 2013 dalam Lup dkk., 2015).

Selain itu, individu dengan perfectionistic self-presentation yang tinggi sangat rentan untuk mengalami kecemasan sosial jika mereka sering menerima umpan balik negatif dari orang lain dan merenungkan pendapat negatif tersebut (Nepon dkk., 2011). Sedangkan, Instagram sendiri memiliki fitur yang menonjolkan pada aspek umpan balik, seperti 'like' atau suka dan komentar, dimana hal tersebut membuat remaja akhir sangat rentan untuk menerima umpan balik negatif, karena setiap pengguna dalam Instagram memiliki kebebasan dalam memberikan umpan balik kepada pengguna lainnya.

Kelemahan dari penelitian ini adalah kurangnya informasi yang diperoleh mengenai karakteristik partisipan dalam hal perilaku mereka menggunakan Instagram, seperti rata-rata durasi penggunaan Instagram dalam sehari. Disebabkan oleh kesalahan peneliti, data yang didapatkan mengenai durasi tersebut tidak dapat digunakan karena terdapat kesalahan dalam pilihan jawaban. Walaupun tidak mengganggu data utama yang ingin diperoleh, penelitian ini tidak dapat melihat analisis tambahan berupa perbandingan antara rata-rata durasi penggunaan Instagram dengan perfeksionisme dan kecemasan sosial. Selain itu, penelitian ini juga tidak dapat melakukan analisis perbandingan antar gender karena subjek yang didapatkan pada penelitian ini memiliki perbandingan gender yang sangat besar, yaitu laki-laki hanya 13,5\%.

\section{S I M P U L A N}

Berdasarkan hasil analisis yang telah dilakukan, dapat disimpulkan bahwa terdapat hubungan antara perfeksionisme dengan kecenderungan kecemasan sosial pada remaja akhir pengguna Instagram. Penelitian mengenai kedua variabel tersebut dalam konteks media sosial masih belum banyak dilakukan, terutama pada media sosial Instagram. Dibandingkan dengan popularitasnya, penelitian mengenai Instagram sendiri masih belum banyak dilakukan. Diharapkan hasil penelitian ini dapat memberikan tambahan pengetahuan dan dapat dijadikan bahan kajian lebih lanjut untuk penelitian selanjutnya yang akan meneliti mengenai hubungan antara kesehatan mental dan media sosial. 
Bagi penelitian selanjutnya, disarankan untuk memperoleh lebih banyak data mengenai perilaku partisipan menggunakan media sosial seperti durasi, jumlah unggahan, dsb., sehingga dapat dilakukan analisis tambahan. Selanjutnya, disarankan pula untuk memperoleh jumlah partisipan lebih besar untuk mewakili populasi secara umum. Bagi remaja akhir pengguna Instagram disarankan untuk mengetahui batasan dimana media sosial tersebut sudah tidak baik lagi bagi kesehatan mental mereka dan disarankan mereka dapat mengelola ekspektasinya, seperti yang dijelaskan sebelumnya bahwa perfeksionisme dapat mengarah pada kecemasan sosial karena individu tidak mampu menampilkan standarnya yang tidak realistis. Bagi tenaga profesional psikologi, disarankan dapat mengolaborasikan penggunaan media sosial sebagai sarana untuk mempromosikan dan melakukan intervensi masalah kesehatan mental.

\section{U C A P A N T E R I MAKASIH}

Peneliti ingin mengucapkan bentuk terima kasih kepada pihak-pihak yang turut berkontribusi dalam penelitian ini. Terima kasih kepada seluruh dosen pengajar dan staf di Fakultas Psikologi Universitas Airlangga, partisipan pada penelitian ini, dan seluruh pihak yang tidak dapat disebutkan satu-persatu.

\section{DEKLARASI POTENSI TERJADINYAKONFLIK KEPENTINGAN}

Belinda Fidi Madani \& Tri Kurniati Ambarini tidak bekerja, menjadi konsultan, memiliki saham, atau menerima dana dari perusahaan atau organisasi mana pun yang mungkin akan mengambil untung dari diterbitkannya naskah ini.

\section{PUST AKA ACUAN}

American Psychiatric Association. (2013). Diagnostic and Statistical Manual of Mental Disorders (Edisi 5).

Anixiadis, F., Wertheim, E. H., Rodgers, R., \& Caruana, B. (2019). Effects of thin-ideal instagram images: The roles of appearance comparisons, internalization of the thin ideal and critical media processing. Body Image, 31, 181-190. https://doi.org/10.1016/j.bodyim.2019.10.005

Antony, M. ., \& Swinson, R. P. (2008). Shyness \& social anxiety workbook (Edisi 2). New Harbinger Publications, Inc.

Butler, G. (1999). Overcoming social anxiety and shyness. Constable \& Robinson Ltd.

Carruthers, S. E., Warnock-Parkes, E. L., \& Clark, D. M. (2019). Accessing social media: Help or hindrance for people with social anxiety? Journal of Experimental Psychopathology, 10(2), 1-11. https://doi.org/10.1177/2043808719837811

Chua, T. H. H., \& Chang, L. (2016). Follow me and like my beautiful selfies: Singapore teenage girls' engagement in self-presentation and peer comparion on social media. Computers in Human Behaviors, 55, 190-197.

Couture Bue, A. C. (2020). The looking glass selfie: Instagram use frequency predicts visual attention to

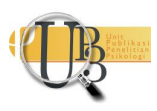


high-anxiety body regions in young women. Computers in Human Behavior, 108, 106329. https://doi.org/10.1016/j.chb.2020.106329

Dhir, A., Yossatorn, Y., Kaur, P., \& Chen, S. (2018). Online social media fatigue and psychological wellbeing-A study of compulsive use, fear of missing out, fatigue, anxiety and depression. International Journal of Information Management, 40, 141-152. https://doi.org/10.1016/j.ijinfomgt.2018.01.012

Erliksson, O. J., Lindner, P., \& Mörtberg, E. (2020). Measuring associations between social anxiety and use of different types of social media using the Swedish Social Anxiety Scale for Social Media Users: A psychometric evaluation and cross-sectional study. Scandinavian Journal of Psychology, 61(6), 819-826. https://doi.org/10.1111/sjop.12673

Flett, G. L., \& Hewitt, P. L. (2014). Perfectionism and Perfectionistic Self-Presentation in Social Anxiety: Implications for Assessment and Treatment. Dalam S. G. Hofmann \& P. M. DiBartolo (Ed.), Social Anxiety: Clinical, Developmental, and Social Perspectives: Third Edition (Edisi 3, hal. 159-187). Elsevier Inc. https://doi.org/10.1016/B978-0-12-394427-6.00007-8

Hamdan, N. (2019, Desember). Pengguna instagram di Indonesia terbesar ke-4 dunia. Tagar. https://www.tagar.id/pengguna-instagram-di-indonesia-terbesar-ke4-dunia

Hamdi, A. S., \& Bahruddin, E. (2014). Metode Penelitian Kuantitatif Aplikasi dalam Pendidikan (A. Anas (ed.)). Deepublish.

Hesler, K. (2015). Perfectionism, Social Support, and Social Anxiety in College Students. Proceedings of GREAT Day, 2015, 9.

Hewitt, P. L., Flett, G. L., Sherry, S. B., Habke, M., Parkin, M., Lam, R. W., McMurtry, B., Ediger, E., Fairlie, P., \& Stein, M. B. (2003). The interpersonal expression of perfection: Perfectionistic selfpresentation and psychological distress. Journal of Personality and Social Psychology, 84(6), 13031325. https://doi.org/10.1037/0022-3514.84.6.1303

Jiang, S., \& Ngien, A. (2020). The effects of instagram use, social comparison, and self-esteem on social anxiety: A survey study in singapore. Social Media + Society, 6(2), 1-10. https://doi.org/10.1177/2056305120912488

Kemp, S. (2020, Januari). Digital 2020: Global digital overview. Data Reportal. https://datareportal.com/reports/digital-2020-global-digital-overview

La Greca, A. M., \& Lopez, N. (1998). Social anxiety among adolescents: Linkages with peer relations and friendships. Journal of Abnormal Child Psychology, 26(2), 83-94. https://doi.org/10.1023/A:1022684520514

Longobardi, C., Settanni, M., Fabris, M. A., \& Marengo, D. (2020). Follow or be followed: Exploring the links between Instagram popularity, social media addiction, cyber victimization, and subjective happiness in Italian adolescents. Children and Youth Services Review, 113, 104955. https://doi.org/10.1016/j.childyouth.2020.104955

Lup, K., Trub, L., \& Rosenthal, L. (2015). Instagram \#Instasad?: Exploring associations among instagram use, depressive symptoms, negative social comparison, and strangers followed. Cyberpsychology, 
Behavior, and Social Networking, 18(5), 247-252. https://doi.org/10.1089/cyber.2014.0560

Mabe, A. G., Forney, K. J., \& Keel, P. K. (2014). Do you "like" my photo? Facebook use maintains eating disorder risk. International Journal of Eating Disorders, 47(5), 516-523. https://doi.org/10.1002/eat.22254

Mackinnon, S. P., Battista, S. R., Sherry, S. B., \& Stewart, S. H. (2014). Perfectionistic self-presentation predicts social anxiety using daily diary methods. Personality and Individual Differences, 56, 143148. https://doi.org/10.1016/j.paid.2013.08.038

Mertens, D. M. (2010). Research and Evaluation in Education and Psychology (Edisi 3). SAGE Publications Ltd.

Müller, K. W., Dreier, M., Beutel, M. E., Duven, E., Giralt, S., \& Wölfling, K. (2016). A hidden type of internet addiction? Intense and addictive use of social networking sites in adolescents. Computers in Human Behavior, 55, 172-177. https://doi.org/10.1016/j.chb.2015.09.007

Nepon, T., Flett, G. L., Hewitt, P. L., \& Molnar, D. S. (2011). Perfectionism, negative social feedback,and interpersonal rumination in depression and social anxiety. Canadian Journal of Behavioural Science, 43(4), 297-308. https://doi.org/10.1037/a0025032

Roccaforte, C., \& Cohen, V. (2017). Creating a strong online identity may contribute to depression, anxiety, and other problems. Anxiety. https://www.anxiety.org/strong-online-social-media-identity-canlead-to-anxiety.

Royal Society for Public Health. (2017). Status of Mind: Social media and young people' s mental health and wellbeing. In Royal Society for Public Health. https://doi.org/10.1371/journal.pone.0055745

Schlenker, B. R., \& Leary, M. R. (1982). Social anxiety and self-presentation: A conceptualization model. Psychological Bulletin, 92(3), 641-669. https://doi.org/10.1037/0033-2909.92.3.641

Shaw, A. M., Timpano, K. R., Tran, T. B., \& Joormann, J. (2015). Correlates of facebook usage patterns: The relationship between passive facebook use, social anxiety symptoms, and brooding. Computers in Human Behavior, 48, 575-580. https://doi.org/10.1016/j.chb.2015.02.003

Sheldon, P., \& Bryant, K. (2016). Instagram: Motives for its use and relationship to narcissism and contextual age. Computers in Human Behavior, 58, 89-97.

Stockdale, L. A., \& Coyne, S. M. (2020). Bored and online: Reasons for using social media, problematic social networking site use, and behavioral outcomes across the transition from adolescence to $\begin{array}{llll}\text { emerging adulthood. Journal of } & \text { Adolescence, } & 79, & \text { 173-183. }\end{array}$ https://doi.org/10.1016/j.adolescence.2020.01.010

Suryaningrum, C. (2016). Efikasi diri dan kecemasan sosial: Studi meta analisis. Jurnal Ilmiah Psikologi Terapan, 4(2), 182-193.

Suryaningrum, C., Retnowati, S., Helmi, A. F., \& Hasanat, N. U. (2019). The development of the Indonesian college student social anxiety scale. International Journal of Research Studies in Psychology, 8(1). https://doi.org/10.5861/ijrsp.2019.3014 
Vannucci, A., Flannery, K. M., \& Ohannessian, C. M. (2017). Social media use and anxiety in emerging adults. Journal of Affective Disorders, 207, 163-166. https://doi.org/10.1016/j.jad.2016.08.040

Vannucci, A., Ohannessian, C. M., \& Gagnon, S. (2019). Use of multiple social media platforms in relation to psychological functioning in emerging adults. Emerging Adulthood, 7(6), 501-506. https://doi.org/10.1177/2167696818782309

Vriends, N., Pfaltz, M. C., Novianti, P., \& Hadiyono, J. (2013). Taijin kyofusho and social anxiety and their clinical relevance in indonesia and switzerland. Frontiers in Psychology, 4(3), 1-9. https://doi.org/10.3389/fpsyg.2013.00003

Winter, J. (2013). Here's why instagram is even more depressing than Facebook. Slate. https://slate.com/technology/2013/07/instagram-and-self-esteem-why-the-photo-sharingnetwork-is-even-more-depressing-than-facebook.html 